\title{
Representation of the axiological component of the concept "house" in the English, German and Russian languages
}

\section{[Репрезентация ценностного компонента концепта «дом» в английском, немецком и русском языках]}

\author{
Tatiana Sergeevna Nifanova - Larisa Georgievna Popova - Natalia \\ Vladimirovna Popova - Lubov Mikhailovna Shatilova - Elena Borisovna \\ Savelyeva - Elena Alexandrovna Lineva
}

DOI: 10.18355/XL.2019.12.02.03

\begin{abstract}
The article deals with the peculiarities of the representation of the axiological component of the phraseological concept "house" in the English, German and Russian languages. Russian is chosen as a basic language for comparison. The name of the chosen concept in Russian is a lexical unit "дом" in English - "house/home" and in German - "Haus". The purpose of the research is to reveal similarities and differences in the representation of the axiological component of the concept "home" in the specified languages. The analysis revealed the similarities and differences in the ways and means of the representation of the axiological component of the studied concept in the compared languages.
\end{abstract}

Key words: concept, representation, linguistic culture, house, idioms, axiological component

\section{Аннотация}

В данной статье на материале английского, немецкого и русского языков рассматриваются особенности репрезентации ценностного компонента фразеологического концепта «ДОМ». Основой сопоставления является русский язык. Именем концепта в русском языке избрана единица «дом», в английском языке - «house / home», в немецком языке - «Наus». Целью исследования выступает установление сходств и различий в репрезентации ценностного компонента концепта «дом» в указанных языках. В результате анализа установлены сходства и различия в путях и способах репрезентации ценностного компонента изучаемого концепта в сопоставляемых языках.

Ключевые слова: концепт, репрезентация, лингвокультура, дом, фразеологизмы, ценностный компонент

\section{Введение}

В последние годы увеличился интерес научного сообщества к когнитивным аспектам языка. В современной лингвистике можно встретить множество работ, посвящённых изучению лингвокультурных концептов, которые затрагивают различные сферы жизнедеятельности человека.

Объектом нашего исследования является концепт «дом» во фразеологических картинах мира английского, немецкого и русского языков. Во фразеологических единицах наиболее полно отражены культурные ценности того или иного народа. Лингвокультурный концепт «дом» является одним из примеров этому.

Концепт «дом» в настоящее время часто выступает объектом исследования языковедческих изысканий. Он считается одним из базовых концептов языка и, по замечанию Ю.С. Степанова, отличается постоянством и длительностью своего существования (Stepanov, 2004). Согласно В.И. Карасику, как и любой концепт, концепт «дом» содержит в себе понятийный, образный и ценностный

XLinguae, Volume 12, Issue 2, April 2019, ISSN 1337-8384, eISSN 2453-711X 
компоненты (Karasik, 2002). Отмечается присутствие научного интереса лингвистов к его вербализации как на материале одного языка, так и в сопоставительном аспекте. Ценностный компонент является доминирующим в структуре концепта, содержит информацию о месте данного концепта в лингвокультуре.

Так, например, Чжан Янь отмечает, что в китайской языковой культуре дом трактуется как помещение, где можно устроить себе спокойную тихую жизнь. Многократное переселение из одного дома в другой рассматривается китайцами как неустроенная жизнь, лишенная стабильности. Понятие «дом» в китайской культуре является предметом первой необходимости при создании семьи. Дом подобен корню дерева; дом способен обеспечить семье надежное пристанище (Chzhan, 2016).

В исследовании В. Цуркан «Антология художественных концептов русской литературы XX века» (Tcurkan, 2013) показана динамика наполнения концепта «дом» на протяжении XX века: усиление социального компонента за счет традиционного ценностного, появление отрицательных коннотаций в эмоциональном слое концепта в начале века, осмысление развала дома как символа распада нравственных основ семьи и государства во второй половине столетия, утверждение идеи восстановления дома как духовной основы в литературе в XX-XXI веков.

Диссертация О.А. Фещенко посвящена анализу концепта «дом» в художественной картине мира М.И. Цветаевой (Feshchenko, 2005) В ходе анализа было установлено, что концепт «дом» включает в свой состав такие признаки, как «жилище», «семья», «здание / строение», «живое существо», «пространство дома», «антидом». При этом значение концепта «дом» характеризуется дополнительно с точки зрения его открытости / закрытости и наполненности духовного мира дома.

В своем диссертационном исследовании «Лингвокультурологическая концептуализация дома в адыгской и английской языковой картине мира» Л.Т. Алчагирова пришла к выводу о том, что важнейшим средством вербализации концепта «дом» в адыгской лингвокультуре является фольклорный фонд, который фиксирует следующие признаки: «кунацкая», «очаг», «дверь», «порог», «пространство за дверью», «ворота», «закрома», «спальня» и «окно». В отличие от адыгской, в английском фольклоре выражение получают признаки «жилище отшельника», «сельский домик», «дом», «замок», «башня», «дворец», «опочивальня» (Alchagirova, 2016).

Т.У. Матназаров и У.В. Хоречко утверждают, что общими признаками концепта «дом» в русской и китайской языковых картинах мира являются «жилище» и «группа живущих вместе родственников». При этом перечень родственников, которые имеются в виду, в китайском языке, гораздо длиннее, чем в русском языке. Вместе с тем, авторы указывают и на различия. В частности, только для русского языка свойственны такие признаки, как «домовина / гроб» и «дом в детских играх, то есть, место, где нельзя преследовать». Лишь в китайском языке дом выступает в роли счетных слов и суффикса, который служит для образования названий некоторых специальностей (Matnazarov, Horechko, URL: https://moluch.ru/archive/85/16068/, 2016).

Крайне интересной представляется диссертационная работа Л.А. Базыловой «Средства репрезентации концепта ДОМ в русском и английском языках (на материале романа А.Г. Битова «Пушкинский дом» и его немецкоязычного перевода)», анализируя средства репрезентации концепта «дом» в русском и немецком языках, установила, что ядро концепта «дом» русского языка формируют такие признаки, как «жилище», «здание / строение», «живущие вместе люди», «Родина», «учреждение», «род / династия», «очаг», тогда как в центре одноименного концепта в немецком языке находятся признаки «дом / 
строение», «жилье / помещение / квартира», «вместе живущие люди», «быт / хозяйство семьи», «династия / род», «учреждение» и «страна» (Bazylova, 2010). Обращаясь к истории становления данного концепта в английской лингвокультуре в диахроническом аспекте, С.В. Воробьева выделяет лингвокультурологическое поле «дом» как одну из сфер повседневной жизни позднего Средневековья. Необходимо отметить, что в лингвистическое поле включаются языковые единицы, денотаты которых соотносятся с конкретными фактами реальности и содержат в себе культурно исторический опыт членов языкового коллектива. Актуализируют в текстах позднего Средневековья понятийный компонент концепта «дом» такие значения, как: здание, предназначенное для жилья; место, где проживает человек; домашнее хозяйство; домашний очаг; родина, место рождения; династия (Vorobyeva, 2011).

В своём известном труде «Славянские языковые моделирующие системы (древний период) отечественные лингвисты В.В. Иванов и В.Н. Топоров включают концепт «дом» в традиционное для русской культуры противопоставление «своего» и «чужого» пространства (Ivanov, Toporov, 1965). Дом близок человеку, данное пространство хорошо понято и осмыслено, это фрагмент «своего» мира. Об этом говорит и Ю.М. Лотман, отмечая такую особенность, что дом становится базой освоения другого внешнего мира через образное воплощение, таких как отгороженность от «чужого» мира, членение и строение, наполнение «своего» пространства и пр. (Lotman, 1992).

Е.А. Потураева, проанализировав понятийную сферу «дом» с точки зрения участия в языковом миромоделировании, воплощенного в метафорических и метонимических наименованиях на материале русского языка, делает выводы о том, что смысловая и эмоциональная нагруженность реалии «дом» находит свое отражение в метафорическом фрагменте русской языковой картины мира (Poturaeva, 2010). Исследователь подчёркивает, что дом осмысляется человеком как неотъемлемая часть его существования. Дом наделяется человеком физическими, социальными, культурными смыслами посредством антропоморфных, зооморфных, фитоморфных и артефак-томорфных образов (Poturaeva, 2010). Подобную точку зрения разделяет Д.Р. Валеева, изучая репрезентацию данного концепта в русской языковой картине мира (Valeeva, 2010). Она также называет данный концепт универсальной культурной константой, которая представлена в русском языке лексическими, словообразовательными единицами, фразеологизмами и паремиями, в которых отражаются характеристики данного концепта. Изучение паремий, репрезентирующих данный концепт, выявляет зоны его пересечения с другими концептами: «Человек», «Семья», «Родина», «Счастье», «Память», «Богатство», «Труд» (Valeeva, 2010). Кроме того, Д.Р. Валеева отмечает, что основными отличиями концепта «дом» в русской языковой картине мира является его соборность и «матрешковость». Первое подчёркивает значимость совместного проживания и ведения хозяйства в доме, а второе указывает на стабильность дома как некой пространственной координаты, которая служит осуществлению взаимосвязи человека и мира и расширению своих границ до размеров Вселенной. В английской языковой картине мира, считает исследовательница, концепт «дом» реализует, прежде всего, признак статусности владельца и выступает как предмет частной собственности. В испанской языковой картине мира, названный концепт ассоциируется с размером жилой постройки, ее освещённостью, а также наличием или отсутствием сада при доме. (Valeeva, 2010).

Анализируемый концепт «дом» способен образовывать совместно с концептом «семья» гиперконцепт «семья/дом», исследованию которого в

XLinguae, Volume 12, Issue 2, April 2019, ISSN 1337-8384, eISSN 2453-711X 
сопоставительном аспекте посвящает свою диссертацию Е.А. Кострубина. Гиперконцепты «Семья/Дом» и «Family/Home» обнаруживают различия в русской и английской культурах по ряду характеристик. Для английского культурного сознания данный гиперконцепт внутренне развертывается от концепта «Дом» к концепту «Семья», а в русской лингвокультуре от Семьи к Дому. Поэтому «Дом» и «Семья» в русской культуре становятся концептуально синонимичными (Kostrubina, 2011).

\section{Цель, методы, актуальность}

Целью данной статьи выступает установление сходств и различий в репрезентации ценностного компонента концепта «дом» в индоевропейских языках, из которых были выбраны английский, немецкий и русский языки. В ходе исследования применялись следующие методы: метод семантического анализа, сопоставительный и сравнительный методы, метод компонентного анализа лексических единиц, выступающих в качестве ядерных лексем репрезентации данного концепта в каждом языке. В качестве основы для сопоставления был выбран русский язык, выступивший в качестве языкаосновы. Репрезентация ценностного компонента исследуемого концепта устанавливалась на базе существующих пословиц, афоризмов на сопоставляемых языках, где употреблялись выявленные ядерные лексемы (Day Babcock, 2015; Davletbaeva, 2010; Gonzalez, Roseano, Borras-Comes, Peieto, 2017; Hajiyeva, 2015; Lanskaya, 2005).

В современном языкознании не ослабевает научный интерес к изучению различных концептов в сопоставительном аспекте. Так, Н.В. Попова (Летуновская) и Л.М. Шатилова в своих научных работах исследовали основополагающие ценностные концепты, соответственно, «красота» и «добро», которые непосредственно связаны с концептом «дом» на лексикофразеологическом уровне («Ищи добра на стороне, а дом люби по старине» или «Изба красна углами, обед - пирогами») (Popova, 2011; Letunovskaya, 2005; Shatilova, 2006, 2011). Дом - это место для души, потому что красота, добро и тепло дома тесно связаны.

Концепт «Дом», как мы отметили выше, неоднократно подвергался исследованию, однако в сопоставительном языкознании недостаточно разработан механизм репрезентации концептов на уровне лексики при сравнении нескольких языков как родственных, так и неродственных, что подчёркивает актуальность данного исследования.

Предметом исследования выступает семантика лексем, составляющих обозначенный концепт в русском, английском и немецком языках.

\section{Сопоставительная характеристика лексем, представляющих данный концепт в русском, английском и немецком языках}

Человек, живя среди других людей, то есть в обществе, привязан не только к своей семье, но и к родному дому. В русском языке под словом «дом» понимается жилое (или для учреждения) здание, а также (собирательное) люди, живущие в нем. При встрече можно услышать вопрос: Ну как там у тебя дома? Задающий этот вопрос хочет узнать о новостях в семье.

Под домом, следовательно, понимается не только квартира или жилье, но и семья, люди, живущие вместе, их хозяйство. Домом называют также учреждения, заведения, обслуживающие какие-нибудь общественные нужды, типа Дом культуры, Дом ребенка и т.п. Под этим словом в русском языке также подразумевают династию, род. Но эта сема относится к разряду устаревших значений (Dal, URL: http://dal.slovaronline.c om/S/SJo/37766-SERP; Ushakov, 1996). 
Само слово «дом», согласно этимологическим данным, можно встретить и в других родственных языках, сравните: украинский - дім, старославянский ДОМЪ, болгарский - домът, сербохорватский - доิм, словенский - dôm, чешский - dům, словацкий - dom, польский, верхнелужицкий, нижнелужицкий - dom. Старинная основа слова на “u” родственна древнеиндийскому damos

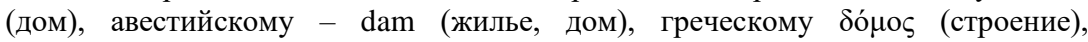
латинскому domus, древнеисландскому timbr (строительный лес), прогерманскому tumfetiz (место строительства), литовскому dimstis (поместье, имение), готскому timrjan (строить, воздвигать), литовскому nãmas (дом), латышский nams (вид кухни) (Fasmer, 1996).

В английском языке этой лексеме соответствуют лексемы house, home. По данным английского этимологического словаря, лексема house имеет следующее происхождение: House - др. англ. hus "dwelling, shelter, house", берущее начало из протогерманского khusan (cp. др.-норв., др.-фризск. hus, дат. huis, нем. Haus), неясного происхождения, возможно, связанного с основой глагола hide (прятать, скрывать). В готском языке лексема использовалась только в значении «храм» (букв. god-house); в значении "family, including ancestors and descendants, especially if noble" она стала употребляться с 1000 года (Concise Oxford Dictionary of English Etymology, 2003).

Современные толковые словари английского языка фиксируют лексему house как многозначную, придавая ей от пяти до девяти значений; основными являются следующие: house - a building that is made for one family to live in; house - a building that serves as living quarters for one or a few families; house housing that someone is living in. Основными семами являются building, living, someone / family (Longman, 2007).

Лексема home восходит к древнеанглийской лексеме ham и означает "dwelling, house, estate, village". Эта лексема, так же как и лексема house, многозначна и представлена разным количеством сем в разных словарях.

B немецком языке дом - это das Haus. Данное слово по своему происхождению является общегерманским словом. Само слово относится к разветвленной группе слов индоевропейского корня [s] keu (накрыть, укрывать, оборачивать). Данная лексема в немецком языке обозначает здание, предназначенное человеку для жилья. В древности она имела ещё значения: домашнее хозяйство, семья (Duden. Herkunftswörterbuch, 1997; Deutsches Universalwörterbuch, 2007).

Целесообразно сопоставить и другие синонимические лексеме «дом» обозначения, существующие в русском языке. К числу таких синонимов можно причислить: здание, хижина, изба.

Обратимся к сопоставительному анализу русского слова «здание» с аналогичными лексическими обозначениями в рассматриваемых языках. Под зданием в русском языке понимается архитектурное сооружение, постройка.

Само слово имело в старославянском языке вид ЗЬДАНИЕ. Оно образовано от «здать: создать», от русского церковнославянского создаде. Оно встречается в других родственных славянских языках, сравните: болгарский - зидам (строю), сербохорватский - зидати (сооружать из камня), словенский - zidati (класть стену), чешский - zed' (каменная стена), польский - zdun (гончар). Само слово родственно словам из других индоевропейских языков. Сравните: литовский žiedžiù (формовать, лепить), латышский ziest (обмазывать глиной), древнепрусский seydis (стена), готский deigan (месить, мять), древнеиндийский

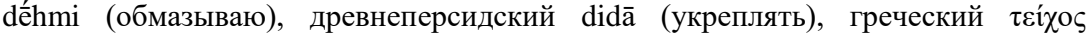
(каменная стена), латинский fingō (мажу) (Fasmer, 1996).

В английском языке здание - это building. Слово появилось в языке с 1300 года, имело значение «структура»; а с конца 14 века появляется значение «действие или процесс построения», существительное образовано от глагола build (v.),

XLinguae, Volume 12, Issue 2, April 2019, ISSN 1337-8384, eISSN 2453-711X 
который в древнеанглийском языке имел форму byldan «строить дом», восходит к протогерманскому * buthla- (сравните: древнесаксонский bodl, древнефризский bodel «здание, дом»), от индоевропейского* bhu, от корня * bheue- «быть, существовать, расти» (Concise Oxford Dictionary of English Etymology, 2003). В Соединенных Штатах этот глагол используется с гораздо большей широтой значений, чем в Англии.

В немецком языке здание - это das Gebäude. Слово в средневерхненемецком языке имело форму gebūwede, в древневерхненемецком языке это было gebūwida от глагола bauen и означало «строение». Современное значение данного слова в немецком языке - большое строение. Сам глагол bauen восходит к индоевропейскому корню "bheu-" в значении «расти, возникать, становиться, быть, жить». Он родственен русскому «быть» (Duden. Herkunftswörterbuch, 1997; Deutsches Universalwörterbuch, 2007).

Сопоставление, таким образом, показывает, что русское слово «здание» обладает универсальным значением «строение», которое отмечается как присутствующая сема в аналогичных лексемах в родственных и неродственных языках. Наряду с этим слово отражает скрытую сему «постройка именно из камня», которая отмечается в значениях аналогичных лексем родственных языков.

Обратимся к сравнению лексем, обозначающих слово «хижина» в русском и других родственных языках. Вначале хотелось бы отметить, что само слово обозначает в русском языке небольшой сельский домик типа избушки. Аналогичное название отмечается и в других родственных языках. Так сравните: украинский - хижа, русский церковно-славянский - хыжа, хыжда, болгарский - хижа (жилье, землянка), сербохорватский - хӥжа (дом), хӥжина (комната), словенский - híža (дом), чешский chyže, chyžina, словацкий chyža, польский - диалектный - chyża, chyż (шалаш), верхнелужицкий khěža, нижнелужицкий сhуžа. Слово произошло от основы хуzъ (дом) со славянским суффиксом -ia под влиянием славянского слова kotia (хижина, дом). Основообразующее славянское слово близко германскому слову hûs (дом). Хизок - это в русском языке амбарчик, где спят молодые, холодная изба, где спят летом (Fasmer, 1996).

В английском языке хижина - это hut. По своей этимологической характеристике оно происходит из французского hutte «коттедж» (16в.), сравните: средневерхненемецкое hütte «коттедж, хижина», вероятно, из протогерманского hudjon-, который связан с корнем древнеанглийского hydan «спрятаться» от индоевропейского keudh-, от корня "keu“, чтобы покрыть, скрыть. По-видимому, сначала на английском языке оно появилось как военное слово. Сравните: древнесаксонский hutta, датский hytte, шведский hytta, фризский и среднеголландский hutte, голландский hut (хижина) - (Concise Oxford Dictionary of English Etymology, 2003).

В немецком языке хижина - это die Hütte. Это слово имеет ограничения в определении своего начального значения и формы. Оно имеет место лишь в немецком языке. В древневерхненемецком языке hutta, в средневерхненемецком языке hütte. Оно происходит из индоевропейского корня [s]keu в значении «покрывать, оборачивать». В немецком языке было и древнее значение этого слов - палатка, торговая палатка, которую строили как временное укрытие из подручных средств. Оно использовалось как место охраны от набегов. В горном деле это был сарай, где хранили руду и орудия труда.

В средневерхненемецком языке появилось значение этого слова - строение или предприятие, где плавили руду. В современном немецком языке таким словом называют бедное, порой запущенное жилье, строение (Duden. Herkunftswörterbuch, 1997; Deutsches Universalwörterbuch, 2007). 
Сопоставление показывает тот факт, что в русском слове «хижина» наряду с универсальным значением «маленький и бедный домик» сохраняется и индоевропейское значение - строение временного плана, построенное не для длительного проживания из подручных средств.

В русском языке существует и ещё одно наименование строения - изба. Под избой понимают на Руси истопку. Согласно данным этимологического словаря это слово можно встретить в других языках. Сравните: украинский - ізба, древнерусский - ИСТЬБА - дом, баня, церковнославянский - ИСТЬБА, болгарский - изба - землянка, хижина, сербохорватский - изба - комната, погреб. Словацкий izba, jispa, jspa - комната, чешский - jisba - комната, славацкий - izba - комната, польский - izba, žba - комната, палата, верхнелужицкий - jstwa, stwa, нижнелужицкий - špa, spa, полабский - jazba. Oт слова «топить» и произошло слово «изба», в своей праславняской основе јъstъba оно заимствовано от германского stuba (сравните: древневерхненемецкий stuba - тёплое помещение, баня, древнеисландский - stofa, stufa - баня с печью, романский extūfa (французский - étuve, итальянский - stufa - баня) - (Fasmer, 1996). Согласно данным толкового словаря русского языка под избой понимается деревянный крестьянский дом (Dal, URL: http://dal.slovaronline.c om/S/SJo/37766-SERP).

$\mathrm{B}$ английском языке изба - это hut, этимологическая характеристика которого была представлена выше. Обратимся к немецкому языку. В нем крестьянский дом так и называется крестьянским домом - das Bauernhaus. Само слово образовано от глагола bauen. Это древний германский глагол. Сравните: древневерхненемецкий - būan, нидерландский - bouwen, древнеанглийский būan, шведский - bo, готский - bauan. Сам глагол относится к индоевропейскому корню "bheu-“" со значениями: расти, возникать, преуспевать, процветать, становиться, быть, жить. Глагол проявляет сходство с греческим physis (природа), латинским fuisse (был), futurus (будущий), древнеиндийским bhavati (есть, быть), литовским būti (быть), русским быть (Duden. Herkunftswörterbuch, 1997; Deutsches Universalwörterbuch, 2007).

Таким образом, русское слово «изба» обладает наряду с универсальным значением «здание, помещение, дом» индоевропейским древним значением «помещение именно с печью». Причем второе из перечисленных значений как бы уже потерялось в современном русском языке, так как каждое из помещений в современной повседневной жизни обязательно отапливается.

Данный перечень нельзя считать завершенным, так как могут быть и другие наименования в русском языке дома. Но как показывает сопоставительный анализ, в русском языке наименования дома сохраняют семы универсального и индоевропейского характера.

Исследование может быть представлено в виде таблицы. 


\begin{tabular}{|c|c|c|}
\hline Русский язык & Английский язык & Немецкий язык \\
\hline 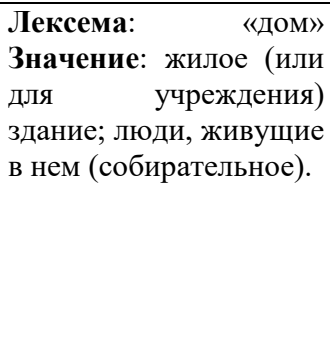 & $\begin{array}{l}\text { Лексема: «house», } \\
\text { «hоте» } \\
\text { Значение: house - } \\
\text { здание, построенное } \\
\text { для проживания } \\
\text { одной семьи; здание, } \\
\text { которое служит } \\
\text { жилым помещением } \\
\text { для одной или } \\
\text { нескольких семей. }\end{array}$ & $\begin{array}{l}\text { Лексема: das Haus } \\
\text { Значение: } \\
\text { предназначенное } \\
\text { человеку для жилья. }\end{array}$ \\
\hline $\begin{array}{l}\text { Лексема: «здание». } \\
\text { Значение: } \\
\text { архитектурное } \\
\text { сооружение, } \\
\text { постройка. }\end{array}$ & $\begin{array}{l}\text { Лексема: building. } \\
\text { Значение: действие } \\
\begin{array}{l}\text { или } \\
\text { построения. }\end{array}\end{array}$ & $\begin{array}{l}\text { Лексема: das Gebäude. } \\
\text { Значение: } \\
\text { строение. }\end{array}$ \\
\hline $\begin{array}{l}\text { Лексема: «хижина». } \\
\text { Значение: маленький и } \\
\text { бедный } \\
\text { строение вомик; } \\
\text { плана, построенное не } \\
\text { для длительного } \\
\text { проживания } \\
\text { подручных средств. }\end{array}$ & $\begin{array}{l}\text { Лексема: hut. } \\
\text { Значение: } \\
\text { небольшой сельский } \\
\text { домик типа избушки. }\end{array}$ & $\begin{array}{l}\text { Лексема: die Hütte. } \\
\text { Значение: бедное, порой } \\
\text { запущенное жилье, } \\
\text { строение. }\end{array}$ \\
\hline $\begin{array}{l}\text { Лексема: «изба». } \\
\text { Значение: деревянный } \\
\text { крестьянский дом; } \\
\text { помещение именно с } \\
\text { печью. }\end{array}$ & $\begin{array}{l}\text { Лексема: hut. } \\
\text { Значение: } \\
\text { небольшой сельский } \\
\text { домик типа избушки. }\end{array}$ & $\begin{array}{l}\text { Лексема: das Bauernhaus. } \\
\text { Значение: крестьянский } \\
\text { дом. }\end{array}$ \\
\hline
\end{tabular}

\section{Сопоставительная характеристика лексем, представляющих концепт «дом» в русском, английском и немецком языках}

\section{Репрезентация ценностного компонента исследуемого концепта в русских паремиях и фразеологизмах}

«Дом - семья»

Под домом понимается не только строение, где кто-то живет, но и семейный уклад, типа:

В каждой избушке свои погремушки.

Погремушка (гремок, гремушка, бубенчик, болхарь) на Руси обозначала не только детскую игрушку, но и могла указывать на принадлежность шута, дурака по званию. Еще под детской игрушкой понимается чья-либо слабость, чей-то односторонний взгляд и убеждение, высказанное, кстати, и некстати (Dal, URL: http://dal.slovaronline.c om/S/SJo/37766-SERP). В каждой семье есть своя специфика, свои слабости и недостатки. Как не вспомнить и другую пословицу: В семье не без урода.

Все смешалось в доме Облонских.

Эта паремия взята из сочинения Л.Н. Толстого «Анна Каренина» и демонстрирует опять же особенности семейного уклада, его своеобразие и противоречивость. 
Но есть и другие паремии, где дом является оплотом семейного, родительского очага, где всегда тепло, где царит уют.

Под крышей дома твоего.

«Дом - организация»

В русских паремиях дом как здание ассоциируется с организациями, которые в нём располагаются.

Дом на Лубянке (Комитет государственной безопасности СССР),

Лубянкой называли улицу, где располагалось здание КГБ.

Дом свиданий, терпимости (публичный дом),

Желтый дом (сумасшедший дом),

Желтым называли этот дом потому, что в Петербурге такое заведение, Обуховская больница, было окрашено в желтый цвет. (Dal, URL: http://dal.slovaronline.c om/S/SJo/37766-SERP).

Мертвый дом (место заключения на каторге).

«Дом - внешность и характер человека»

Номинация дома может быть связана с внешностью и характером человека:

Брови домиком (о бровях в виде угла вверх).

Не все дома (шутливое или пренебрежительное выражение о человеке со странностями, о глупом человеке).

Выражение означало буквально, что не все члены дома, кто-то отсутствует. И этим подразумевается, что отсутствует что-то существенное.

\section{Отражение ценностного компонента концепта «дом» в английском языке «Дом - орган власти или учреждение»}

- the Third House (третья палата Парламента); кулуары Конгресса

- the White House Белый дом; правительство США, заседающее в здании именно белого ивета;

- house of call извозчичья биржа; помещение, где собираются извозчики в ожидании клиентов;

- public house mpakmup;

- God's (Lord's) house церковь; Божий дом, храм Господен;

- dress the house: a) заполнить театр зрителями с пропусками $u$ контрамарками, б) так рассадить зрителей, чтобы театральный зал казался полным;

- bring down the house: покорить весь зал, вызвать бурные аплодисменты, гром аплодисментов;

- home of lost causes: “пристанище несбывшихся амбиций» (прозвище Оксфордского университета).

«Дом как порядок»

- put (или set) one's (own) house in order: a) навести порядок в собственном доме, устрочть свои дела, привести свои дома в порядок (Библейское), б) исправиться, изжить свои недостатки, исправить свои ошибки;

- a rough house: a) шумная ссора, драка, расправа, насилие (первоначально Американское), б) беспорядок, иумная игра, возня;

- throw the house out of the windows: перевернуть все верх дном.

«Дом как осознание, чувство, отклик»

- close to home: a) задеть чви-либо чувства, задеть за живое;

- come (get, go, hit или strike) home: a) попасть в ијель (об ударе и m.n.), б) попасть в цель, в точку, не в бровь, а в глаз. Задеть за живое, найти отклик в чьей-либо душе, растрогать кого-либо, в) доходить до чьего-либо сознания, осознать;

- drive home to: a) суметь доказать, убедить, втолковать, довести до сознания, вбить в голову, б) доводить до конца, успешно завершать;

XLinguae, Volume 12, Issue 2, April 2019, ISSN 1337-8384, eISSN 2453-711X 
- go (all) round the houses: a) ходить вокруг да около;

- a half-way house: компромисс (буквально «гостиница на полпути между городами»).

«Дом - как лучшее место, которое ассоциируется с безопасностью, уверенностью»

- be (feel) at home: a) чувствовать себя как дома, вести себя непринужденно, быть в своей стихии, быть хорошо знакомым с предметом, быть как рыба в воде;

- home and dry: в безопасности.

Именно лексема dry подчеркивает значимость дома, где сухо и тепло. Сравните другую английскую идиому: not to have a dry stitch on (промокнуть до нитки).

«Дом как символ гостеприимства»

- be at home to somebody: a) быть дома для кого-либо, быть готовым принять кого-либо;

- keep open house: a) держать двери дома открытыми (для гостей), жить на широкую ногу, устраивать приемы, славиться гостеприимством;

- make somebody free of one's house: a) радушно принять кого-либо, предоставить свой дом в чье-либо распоряжение б) сделать так, чтобы гости чувствовали себя как дома.

«Дом как некое начинание, которое строится на той или иной основе»

- build one's house upon a rock: a) строить свой дом на скале, то есть создавать что-либо на прочном фундаменте;

- build one's house upon the sand: a) строить свой дом на песке, то есть создавать, основывать что-либо не имея прочного фундамента.

«Дом как место, в котором неуместно совершать определенные поступки»

- name not a halter (или rope) in his house that hanged himself (или was hung): 8 доме повешенного не говорят о веревке;

- people (или those) who live in glass houses should not throw stones: живущий $в$ стеклянном доме не должен бросать в других камни, то есть не следует осуждать других тому, кто сам небезупречен.

«Лишение дома воспринимается как серьезнейшая потеря»

- turn somebody out of house and horse: выгнать, выставить кого-либо из дома;

- eat somebody out of house and horse: разорить кого-нибудь.

«Дом - родина»

East or west - home the best (Восток или запад, но дома лучше всего).

Фразеологическая репрезентация ценностного компонента концепта «дом» в немецком языке

В немецком языке во фразеологизмах присутствует значение

«Дом - семья»

Здесь понимается под домом семейный уклад, семья.

Aus gutem Hause sein. (Быть из хорошей семьи)

Mit vielem hält man Haus, mit wenigem kommt man aus (Большими, добрыми затратами содержится семейный уклад, но мало сохраняется, когда покидают родительский дом).

Однако в немецком языке через паремии прослеживаются такие значения, которые составляют специфику в этом языке. Это и номинация закадычного друга.

«Дом - образ старого, доброго друга»

Altes Haus ( Старина),

«Дом - внутренний покой»

Damit bleib mir zи Hause (не приставай ко мне с этим),

«Дом (как здание) - образец чистоты и покоя, порядка». 
Ein Loch im Dache verdirbt das ganze Haus. (Дыра в крыше вредит всему дому).

Wenn die Scheune brennt, ist das Haus in Gefahr.(Если сарай горит, то это опасно и для всего дома).

$\mathrm{Zu}$ Hause ruht man am besten. (Лучше всего отдыхать дома).

Wetten bringt um Haus und Betten. (Неурядицы разрушают дом и супружество).

«Старый дом - символ недолговечности»

Altem Haus und neuem Freund ist nicht leicht zu trauen. (Не легко доверять старому дому и новому другу).

Дом в немецких пословицах ассоциируется с надежным укрытием от невзгод, это реальная опора в жизни, даже если это просто хижина.

«Собственный дом - опора в жизни»

Lieber eine Hütte auf der Erde als einen Thron in den Wolken. (Лучше хижина на земле, чем трон в облаках).

\section{Сопоставительная характеристика репрезентации ценностного компонента изучаемого концепта в родственных индоевропейских языках. Выводы.}

Анализ полученных данных показал, что в исследуемых языках - русском, английском и немецком - при актуализации ценностного компонента концепта «дом» фиксируются как сходства, так и различия при явном доминировании последних.

К сходствам относятся, во-первых, трактовка дома в английском и русском языках как некоей организации. Во-вторых, как в русском, так и в немецком языке дом ассоциируется с образом семьи, причём семьи с добрым укладом.

Наиболее значительные различия при актуализации ценностного компонента концепта «дом» в изучаемых языках отмечаются между английским и другими изучаемыми языками. В английской культуре ценностный компонент концепта «дом» получает наиболее многообразную качественную и количественную фиксацию. У англичан дом ассоциируется с порядком; осознанием, чувством, откликом на что-либо; безопасным местом; символом гостеприимства; неким начинанием; местом, в котором неуместно совершать определённые поступки; символизирует основу жизни; родину.

Только для немецкого языка свойственно понимание дома как старого и надёжного друга; символа недолговечности, если дом старый; опоры в жизни; своей собственности.

В русском языке дом трактуется наиболее узко - как характер человека, причём чаще подчёркиваются негативные черты человеческого характера.

Незначительные сходства и большие различия в особенностях ценностного понимания концепта «дом» в русском, английском и немецком языках обусловлены, вне всякого сомнения, внешними и внутренними факторами развития сопоставляемых языков, при этом чётко отделить первые от вторых порой достаточно трудно, что, в свою очередь, определяет, на наш взгляд, дальнейшее исследование обозначенной проблемы.

\section{Bibliographic references}

ALCHAGIROVA, L.T. 2016. Lingvokulturologicheskaya konceptualizaciya doma v adygskoi i angliiskoi yazykovoi kartine mira: diss. kand. filol. nauk 10.02.19. Nalchik. 179 p.

ANDREEVA, M.P. 2011. Sociocentricheskie frazeologizmy frazeotematicheskogo polya «MAISON» V sovremennom francuzskom yazyke: diss. kand. filol. nauk: 10.02.05. RGPU im. A.I. Gercena, Sankt-Peterburg. 260 s.

ARZHANOVSKAYA, A.V. - KULICHENKO, Y.N. - POPOVA, O.Y. - 
BAZYLOVA, L.A. 2010. Sredstva reprezentacii koncepta DOM v russkom i angliiskom yazykah (na materiale romana A.G. Bitova «Pushkinskii dom» i ego nemeckoyazychnogo perevoda): diss. kand. filol. nauk: 10.02.01, 10.02.19. Bryansk. $197 \mathrm{p}$.

CHZHAN, Ja. 2016. Associativnoe pole koncepta DOM v russkom yazykovom soznanii. Vesti Novosibirskogo gos. un-ta. Seriya «Lingvistika i mezhkulturnaya kommunikaciya». vol. 14, issue 4, pp. 39-42. ISSN: 1818-7935.

DAVLETBAEVA, D.N. 2010. Kartina mira v russkoi, angliiskoi, francuzskoi i tureckoi frazeologii (na primere koncepta «SEMYA»). Vestn. Samar. Un-ta. Istoriya, pedagogika, filologiya. n. 5(79), pp. 128-133. ISSN: 2542-0445.

DAY BABCOCK, R. 2015. Rhetorical argument, folk linguistics, and contentoriented discourse analysis: A follow up study. In Ampersand, vol. 2, pp. 61-69. ISSN: 2215-0390.

FESHCHENKO, A.A. 2005. Dom v hudozhestvennoi kartine mira M.I. Cvetaevoi (na materiale prozaicheskih proizvedenii): diss. kand. filol. nauk: 10.02.01. Novosibirsk. 216 p.

GONZALEZ, M. - ROSEANO, P. - BORRAS-COMES, J. - PRIETO, P. 2017. Epistemic and evidential marking in discourse: Effects of register and debatability. In Lingua, volumes 186-187, January-February, pp. 68-87. ISSN: 0024-3841.

HAJIYEVA, K. 2015. A corpus-based lexical analysis of subject-specific university textbooks for English majors. In Ampersand, vol. 2, pp. 136-144. ISSN: 2215-0390.

IVANOV, V.V. - TOPOROV, V.I. 1965. Slavyanskie yazykovye modelirujushchie sistemy (drevnii period). M.: Nauka, $246 \mathrm{p}$.

KARASIK, V.I. 2002. Jazykovoi krug: lichnost, koncepty, diskurs. Volgograd: Izdatelstvo: Peremena. 477 p. ISBN 5-88234-552-2.

KOSTRUBINA, E.A. 2011. Giperkoncept Semya/Dom - Family/Home v russkoi i angliiskoi lingvokulturah: diss. kand. filol. nauk: 10.02.05. Omsk. 159 p.

LANSKAYA, O.V. 2005. Koncept «dom» v yazykovoi kartine mira (na materiale povesti L.N. Tolstogo «Detstvo» i rasskaza «Utro pomeshchika»): diss. kand. filol. nauk: 10.02.01. Kaliningrad. $199 \mathrm{p}$.

LETUNOVSKAYA, N.V. 2005. Leksiko-semanticheskaya reprezentaciya koncepta «krasota» v nemeckom i russkom yazykah: diss. kand. filol. nauk: 10.02.20. Tambov, $173 \mathrm{p}$.

LOTMAN, Y.M. 1992. Pamyat v kulturologcheskom osveshchenii. Izbrannye stati. T. 1. Tallinn: Aleksandra, pp.200-202. ISBN 5-450-01551-8.

MATNAZAROV, T.U. - HORECHKO, U.V. 2015. Koncept «Dom» v russkoi i kitaiskoi yazykovyh kartinah mira. Molodoi uchenyi. issue 5. pp. 654-657. Available online: https://moluch.ru/archive/85/16068/.

POPOVA, N.V. 2011. Dihotomiia konfrontiruyushchih kategorii vo frazeologicheskih kartinah mira nemeckogo i russkogo yazykov: diss. d-ra filol. nauk: 10.01.20. MGOU, M., $496 \mathrm{p}$.

POTURAEVA, E.A. 2010. Metaforicheskie oboznacheniya koncepta «Dom» V russkoi yazykovoi kartine mira. Jazyk i kultura. Issue 1. pp. 58-73. ISBN 978-591711-037-0.

SHATILOVA, L.M. 2006. Leksiko-semanticheskaya reprezentaciya koncepta «dobro» v nemeckom i russkom yazykah: diss. kand. filol. nauk: 10.02.20. MGOU, M., $179 \mathrm{p}$.

SHATILOVA, L.M. 2011. Aktualizaciya lingvokulturologicheskih kategorii eksplicitnosti i implicitnosti kak konceptualnyh dominant $\mathrm{v}$ nemeckoi i russkoi yazykovoi kartine mira: diss. d-ra filol. nauk: 10.01.20. MGOU, M., 415 p.

STEPANOV, Ju.S. 2004. Konstanty: Slovar russkoi kultury. 3-e. izd., ispr. i dop. M.: Akadem. proekt, 991 p. ISBN 5-8291-0388-5.

TCURKAN, V. 2013. Antologiya hudozhestvennyh konceptov russkoi literatury XX veka. Flinta, pp. 27-35. ISBN: 9785976516236. 
VALEEVA, D.R. 2010. Reprezentaciya koncepta «dom» v russkoi yazykovoi kartine mira: diss. kand. filol. nauk: 10.02.01. Kazan. 189 p.

VOROBYEVA, S.V. 2011. Koncept «dom» v srednevekovoi angliiskoi lingvokulture. Izv. Ros. gos. ped. un-ta im. A.I. Gercena. Issue 127, pp. 142-146. ISSN: 1992-6464.

Slovari

BINOVICH, L. Je. - GRISHIN, N.E. Nemecko-russkii frazeologicheskii slovar. Available online: http://bookree.org/reader?file=1345867\&pg=1

CHERNYH, P.Ja. 2001. Istoriko-etimologicheskii slovar sovremennogo russkogo yazyka: V 2 t. T.2. M.: Russkii yazyk, 560 p. ISBN 5-200-02851-5.

BNRS - Bolshoi nemecko-russkii slovar: V 2 t. 1980. T.1. M., 760 p. ISBN: 978-5358-07689-1.

DAL, V.I. Tolkovyi slovar zhivogo velikorusskogo yazyka. T. 4. Available online: http://dal.slovaronline.c om/S/SJo/37766-SERP

KUNIN, A.V. 1984. Bolshoi anglo-russkii frazeologicheskii slovar. 4-e izd., pererab. i dop. M.: Russkii yazyk, 944 p.

MULLER, V.K. 2010. Bolshoi sovremennyi anglo-russkii, russko-angliiskii slovar: Novaya redakciya. M., 715 p. ISBN: 978-5-7717--129-5, 978-5-386-01136-9.

RNS - Russko-nemeckii slovar. LEPIN, E.I. i dr. 1976. M., 848 p.

TSRJAO - Tolkovyj slovar russkogo yazyka Ozhegova S.I. Available online: http://ozhegov.textologia.ru/

USHAKOV, D.N. 1996. Tolkovyj slovar russkogo yazyka, M., 1239 p.

FASMER, M. 1996. Etimologicheskii slovar russkogo yazyka. V 4 t. T. 3. SPb, 831 p. FSRLJA - Frazeologicheskiji slovar russkogo literaturnogo yazyka. Available online: http://phraseology.academic.ru/

CONCISE OXFORD DICTIONARY OF ENGLISH ETYMOLOGY. 2003. Oxford: Univ. print, 552 p. ISBN-13: 9780192830982.

Deutsches Universalwörterbuch. 2007. Mannheim-Leipzig-Wien-Zurich: Dudenverlag, 2016 S. ISBN 978-3-411-05506-7.

DUDEN. Herkunftswörterbuch. 1997. Mannheim: Dudenverlag, 844 S. ISBN: 978-3411-04075-9.

LONGMAN. 2007. Dictionary of Contemporary English. Edinburgh: Pearson Longman, 2082 p. ISBN: 9781447954095.

Words: 5369

Characters: 41198 (26,56 standard pages)

Prof. Tatiana Sergeevna Nifanova, Doctor of Philology

General Linguistics and German Philology Department

Institute for Humanities of Severodvinsk branch of the Nothern (Arctic) Federal University

named after M.V.Lomonosov

6 Tortcev St.

164500 Severodvinsk, Arkhangelsk region

Russia

m.balova@narfu.ru

Prof. Larisa Georgievna Popova, Doctor of Philology

Theoretical and Applied Linguistics Department

Moscow City University

4 2nd Selskochoziaistvenyi Proezd

129226 Moscow

Russia

info@mgpu.ru

XLinguae, Volume 12, Issue 2, April 2019, ISSN 1337-8384, eISSN 2453-711X 
Prof. Natalia Vladimirovna Popova, Doctor of Philology Foreign Languages and Teaching Methods Department Michurinsk State Agrarian University

101 Internatsionalnaya St.

393760 Michurinsk, Tambov region

Russia

info@mgau.ru

Prof. Lubov Mikhailovna Shatilova, Doctor of Philology

Romano-Germanic Philology Department

State University of Humanities and Technology

22 Zelenaya St.

142611 Orekhovo-Zuevo, Moscow region

Russia

rektorat@ggtu.ru

Assoc. Prof. Elena Borisovna Savelyeva, $\mathrm{PhD}$.

Romano-Germanic Philology Department

State University of Humanities and Technology

22 Zelenaya St.

142611 Orekhovo-Zuevo, Moscow region

Russia

rektorat@ggtu.ru

Assoc. Prof. Elena Alexandrovna Lineva, PhD.

Department of English Philology and Translation Studies

State University of Humanities and Technology

22 Zelenaya St.

142611 Orekhovo-Zuevo, Moscow region

Russia

rektorat@ggtu.ru 